\title{
IMPACT OF RECREATIONAL PHYSICAL ACTIVITY ON WOMEN'S MENTAL AND PHYSICAL HEALTH AND QUALITY OF LIFE
}

\author{
Nicolette Kanižai*
}

\section{Abstract}

Hypokinesia is characterized by high expansion and indicates the necessity of physical activity promotion. The aim of the study was to point out the positive effect of physical activity, by examining the impact of recreational physical activity on women's mental and physical health and quality of life. The study included 87 healthy women, 30 in aerobics group, 30 in yoga group and 27 in a group of physically inactive women aged 20-26 years. The level of physical activity, health and psychological status and quality of life in women were measured by anonymous questionnaire. The results were correlated between the three groups of participants and between active and inactive women. Recreational physical activity proved to be a good way to improve overall health and quality of life. Exercise reduces tension, stress, nervousness and irritability, improves the mood and sleep quality.

Keywords: physical activity, exercise, recreation, health, quality of life

\section{Introduction}

Regular physical activity is an important health factor of individuals and the general population (Haskell et al., 2007; Stojiljković, 2011). Physical activity contributes to good physical, psychological and mental feeling, and improves quality of life. In contrast to this, sedentary lifestyle and physical inactivity are the cause of many diseases (Ministarstvo zdravlja Republike Srbije, 2006). Regular recreational physical activity, and achieving and maintaining the optimal level of physical activity has a wide prevention and health effects, and these findings are considered significant achievements of modern medicine (Bauman, Lewicka \& Schöppe, 2005; Killoran, Fentem \& Casperson, 1994).

Health means not only physical health, but satisfactorily psychological, mental and emotional health, which we can achieve and maintain with regular recreational activities (World Health Organization, 2005, 2006).

\footnotetext{
* Corresponding author. Maksima Gorkog 23,25000 Sombor, Serbia, e-mail: kanizain@gmail.com (C) 2013 Faculty of Sport and Physical Education, University of Novi Sad, Serbia
} 
Relationship between physical activity and health is known for a long time (Sharkey \& Gaskill, 2008). Most authors believe that the moderate intensity exercise is the most effective form of physical activity, to achieve the health benefits of movement (Stojiljković, 2008).

Several scientific papers have studied and establish the connection between physical activity and human health, as well as the impact of physical activity on individual organ systems. Many institutions and organizations also confirm the evidence of the positive effects of regular physical activity to improving the functioning of organs, organ systems; it can be said of the organism as a whole. The results of similar studies suggest that physical activity reduces the incidence of diseases, such as coronary heart disease, diabetes, hypertension, colon cancer, arthritis, depression, osteoporosis and total mortality. Beneficial effect of physical exercise is also reflected in the improvement of processes in the body in physically active persons (the metabolism of carbohydrates and fats, hemo-coagulation processes, immune system, mental health, etc.) (Baranowski et al., 1992; Macera, Hootman \& Sniezek, 2003).

In spite of various and numerous studies related to the impact of physical exercise on physical health, smaller number of papers is devoted to examination the influence of an active lifestyle on the physical and mental health and a sense of life satisfaction. The results of research in this field show, that the level of physical activity and good mental health are in high positive correlation. Regular physical activity of moderate intensity prolongs life and improves its quality (Ivetić \& Filipović, 2011).

Recreational physical activity is an effective way to improve health and prevent disease. Sports recreation, as a specific area of physical education, with variety forms of activities, is available to all of us, and it is necessary that recreation be included in our daily life (Medved, 1987; Ugarković, 2001).

Despite these facts, and knowledge of the many beneficial effects of exercise, most people are still inactive. Hypokinesia, or immobility is "the phenomenon of global significance" and is characterized by expansive spreading in our region. This problem points to the necessity of taking strong promotion of physical activity to improve and preserve health (Bouchard, 2007).

Knowing the many positive effects of physical exercise on our health, this work is dedicated to improving the promotion of physical activity.

The aim of this study is to emphasize the positive effects of physical activity, by examining the impact of recreational physical activity on women's physical and mental health and the quality of life.

\section{Method}

The survey was conducted in October of 2012 year. There were a total of 90 participants, but data are presented in this paper refer to 87 participants ( 3 participants were excluded from the study because of incomplete or inadequate data). The study included only healthy females aged 20-26 years. The study was conducted in three groups, namely:

- 30 female students of Faculty of Education in Sombor, University of Novi Sad;

- 30 young women who regularly exercise aerobics (Fitness center View, Sombor);

- 30 young women who regularly exercise yoga (Yoga center, Sombor) (see Table 1). 
Table 1

The participants that were included in the study

\begin{tabular}{lccccc}
\hline Type of activity & $\begin{array}{c}\text { Number of } \\
\text { respondents }\end{array}$ & Average age & $\begin{array}{c}\text { Average length } \\
\text { of training }\end{array}$ & $\begin{array}{c}\text { Number } \\
\text { of training } \\
\text { sessions } \\
\text { per week }\end{array}$ & $\begin{array}{c}\text { Duration of } \\
\text { training }\end{array}$ \\
\hline Aerobics & 30 & 24,37 & $3-6$ month & $3-5$ times & $1 / 2-1$ hours \\
\hline Yoga & 30 & 24,27 & $3-6$ month & $3-5$ times & $1-2$ hours \\
\hline $\begin{array}{l}\text { Physically } \\
\text { inactive }\end{array}$ & 27 & 23,41 & $/$ & & $/$ \\
\hline TOTAL & 87 & 24.01 & $/$ & $/$ & $/$ \\
\hline
\end{tabular}

Students of Faculty of Education were selected in the study because of sedentary lifestyles, they were physically inactive. Aerobics and yoga were selected in the study as well known and popular forms of physical recreation in modern times.

The influence of physical activity on human health was investigated using a questionnaire. Before completing the survey, participants signed a statement that they will voluntarily fill it out. The women were given basic information about the research. Fitness instructors (aerobic and yoga instructors) also signed the statement, and gave their approval to completion tests. All participants were informed about the objectives of the research. The survey was anonymous and contained four sets of questions.

The first group of questions focused on physical activity, whether respondents engage in recreational physical activities-sports; what kind; how many times per week; for how long and what the duration of training session are.

The second set of questions is related to the health status of the participants. These questions were taken from a standardized "SF36" health questionnaire. "SF36" is a short general health questionnaire to assess quality of life in the last four weeks (Golubić, 2010).

The third group of questions related to the examination of mental health. It contained five questions about stress, irritability, emotional problems, sleep and mood.

The fourth group of questions related to the quality of life in women. Questions were related to the assessment satisfaction with leisure time, assessment of the energy needed for daily life, self-satisfaction, satisfaction with relationships with other people, health satisfaction, and general satisfaction with their quality of life.

The data obtained from the survey were classified using the Microsoft Excel computer program, and results are presented in this paper by using tables and graphs. Data processing was carried out by appropriate statistical parameters and tests.

Statistical analysis was performed using descriptive parameters: the arithmetic mean $(\bar{x})$, range, the percentage. All collected data were grouped, and results are displayed graphically. Statistical significance between groups of participants was determined using the $\chi^{2}$ test for nonparametric data. To determine statistically significant differences between parametric data Student's t test was used.

In open-ended questions (response scale of $1-3,1-4,1-5)$ we calculate the average values of response $(\bar{x})$ in group. For questions such as closed (answers YES or NO), the results are shown in percentages. 


\section{RESULTS}

The results showed that physically active participants have a more positive attitude about the health, than inactive group of woman. Differences in the assessment of health status, between aerobics exercisers compared to the inactive group of woman, proved to be statistically significant $(p<.05)$. Yoga exercisers also reported significantly higher scores on health status scale in comparison to the inactive participants $(p<.05)$. The most positive assessment of health status was obtained in aerobics exercisers group $(\bar{x}=4.27)$, then in yoga exercisers group $(\bar{x}=4.07)$, while physically inactive group subjects showed far more negative assessment of their health condition $(\bar{x}=2.96)$ (see Figure 1$)$.

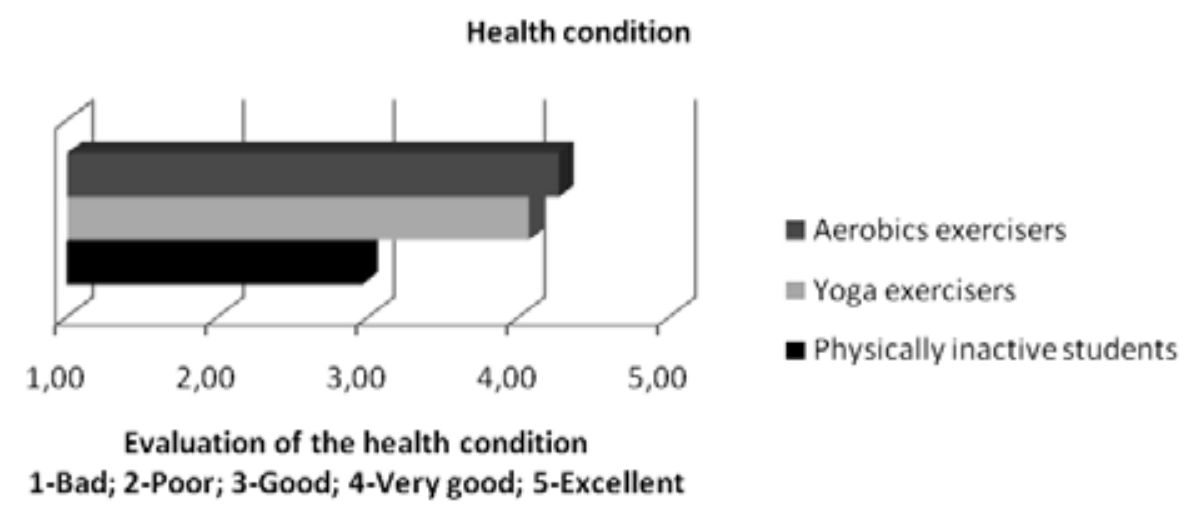

Figure 1. Health condition of the respondents

As for the stress level of the respondents, the data obtained confirmed that physically inactive women felt more stress, tension, or pressure during the previous 4 weeks, than physically active women. Aerobics and yoga exercisers have reported a significantly lower level of stress $(p<.05)$, than physically inactive participants (see Figure 2).

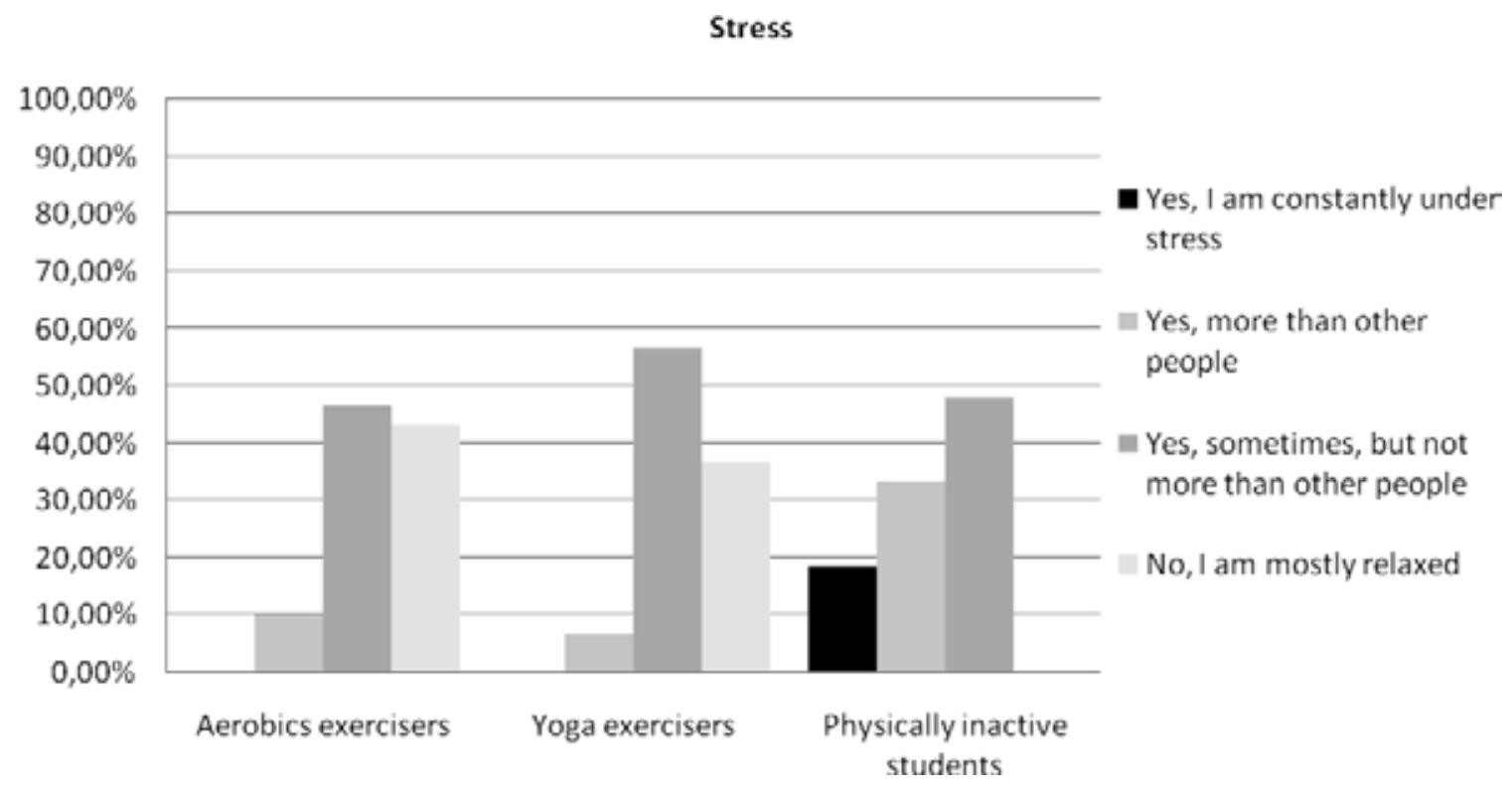

Note: Responses to the question: Are you tense, stressed out / push during the last 4 weeks?

Figure 2. Stress level of the participants 
We affirm the stance that the physically active groups of participants are significantly less stressed out, compared to the inactive group of participants. Differences obtained by surveying about the level of stress show, that aerobics exercisers have significantly lower scores, compared to the inactive group of women $(p<.05)$. Respondents engaged in yoga also have significantly more positive results on the subscale assessing stress, compared to the inactive group of participants $(p<.05)$.

It has been shown that aerobics and yoga exercisers have equally troubling nervousness and irritability, but physically inactive group of participants is significantly different from the first two groups of patients $(p<.05)$, and they are more nervous and irritable than participants engaged in physical recreation (see Figure 3).
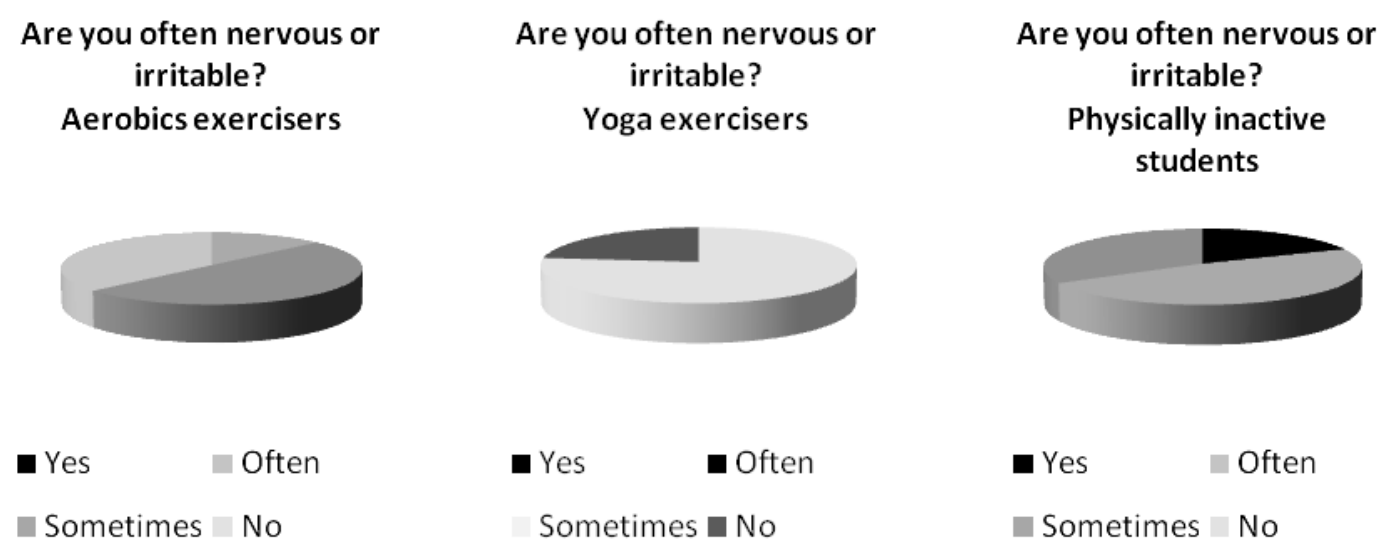

Figure 3. Level of nervousness and irritability in women

Emotional problems in the past 4 weeks were present in all three groups of participants, but physically inactive women had significantly more problems in relation to physically active group of women $(p<.05)$.

The quality of sleep was much better in the active group of participants $(p<.05)$. Insomnia was troubling $48 \%$ of physically inactive patients, while the same problem in a group of yoga exercisers was present in only $10 \%$ of patients. The problem of insomnia and poor quality of sleep was present in only $6.67 \%$ of aerobics exercisers (see Figure 4 ).
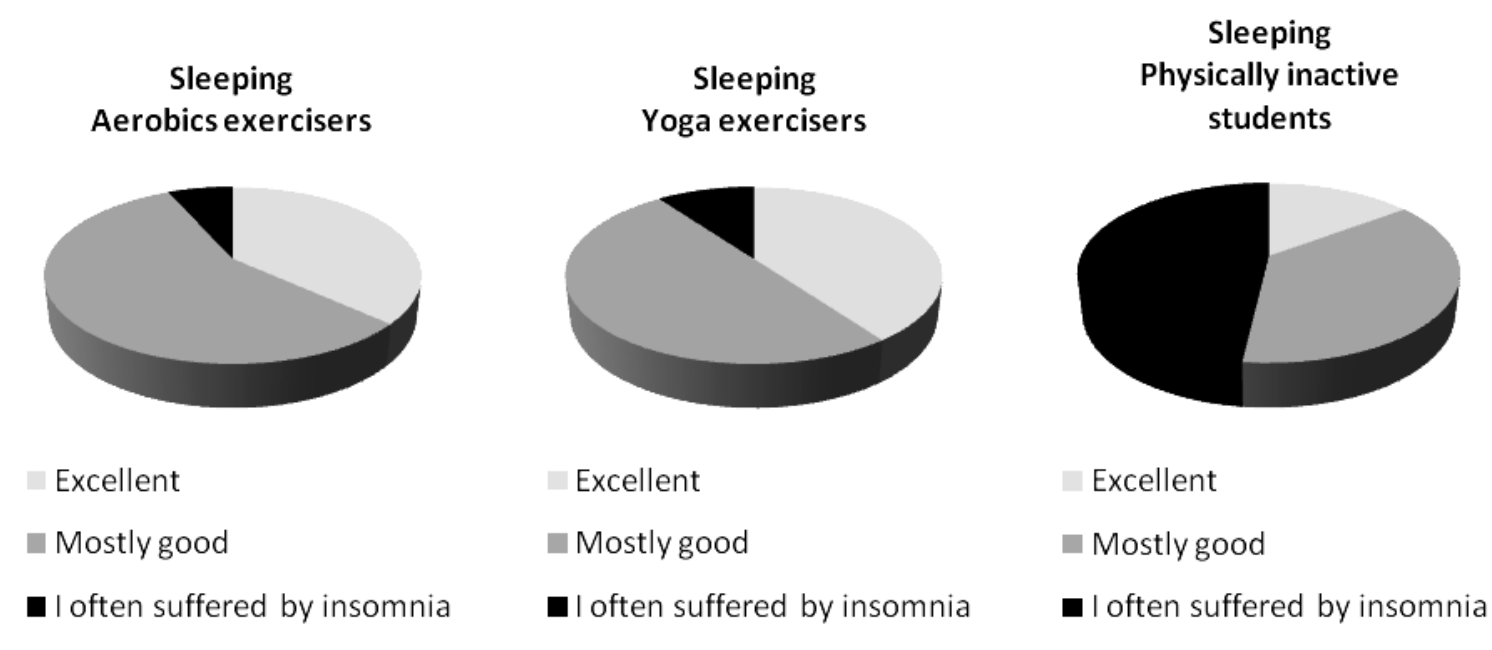

Note: Responses to the question: How do you sleep in the last 3 months?

Figure 4. The quality of sleep 
We collected survey answers about the mood of the participants in the last month. Excellent, well-being mood had 94\% aerobics exercisers, 97\% yoga exercisers, but physically inactive group statistically differed $(p<.05)$ from the previous two groups. In this group, only $55 \%$ of respondents had a good or great mood, and the rest of the women in the group, expressed a bad mood for the last month. Figure 5 shows the average value of the level of mood in groups.

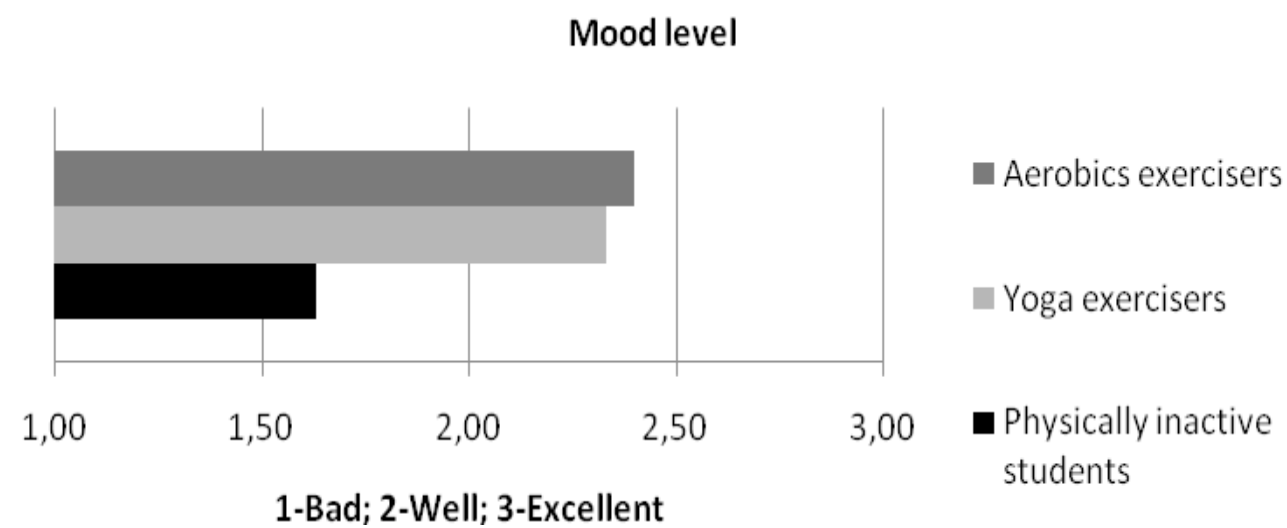

Figure 5. Mood level of respondents

Using survey, we examined the quality of life of participants: the satisfaction with leisure time, satisfaction with energy needed for daily life, self-satisfaction, satisfaction in relationships with other people-communication and health satisfaction. Last question refers to the general satisfaction with one's quality of life. The subjects responded to each question circling the number on a scale of 1 to 5 . Number 1 on the scale meant a very dissatisfied attitude, and number 5 meant very pleased attitude on the scale. The results have shown a statistically significant difference $(p<.05)$, in which a group of physically active exercisers were more satisfied with their quality of life as compared to the inactive group of participants (see Figure 6).

\section{Quality of life}

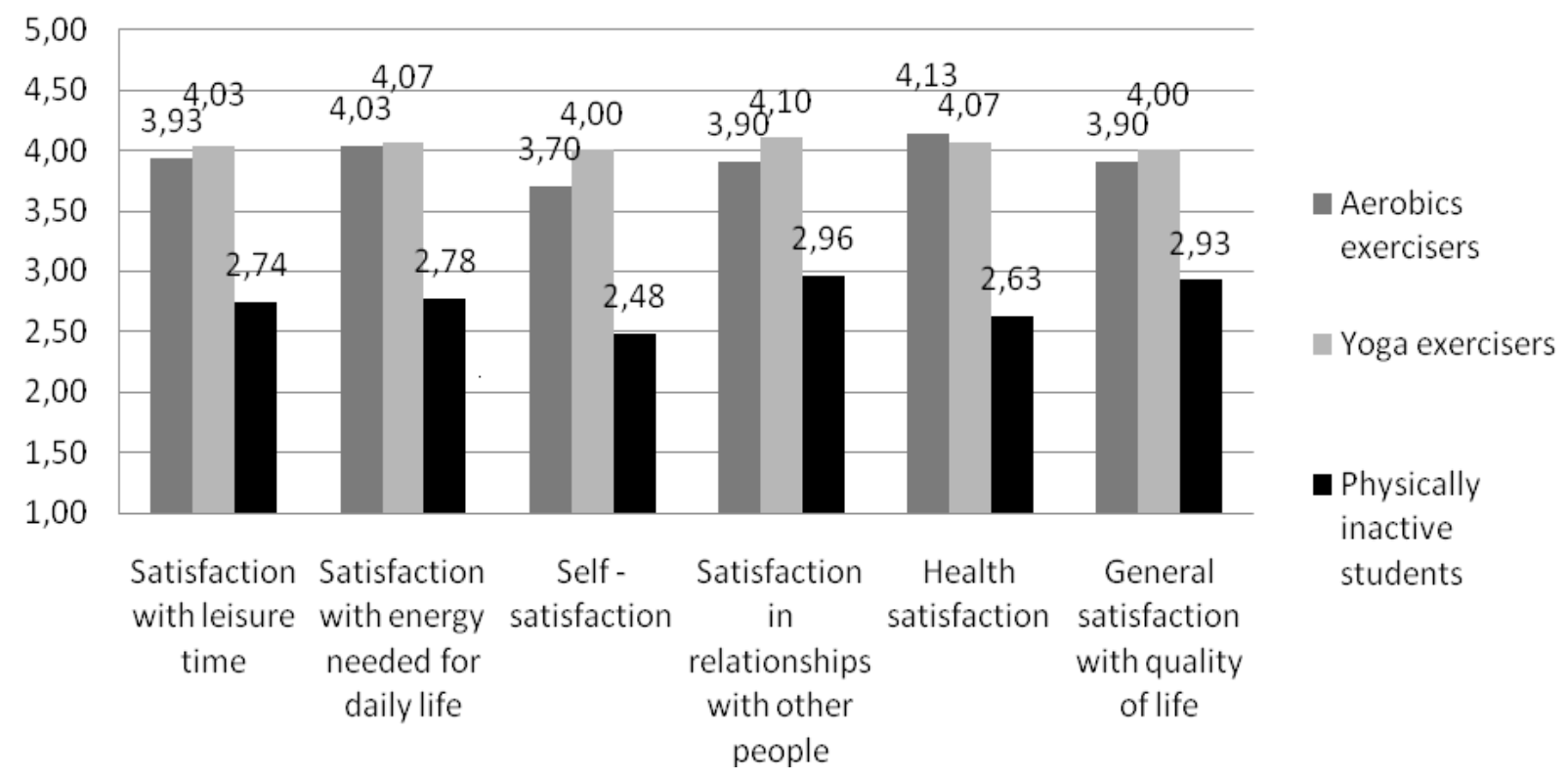

Figure 6. Quality of life 


\section{Discussion}

The study included 87 healthy women divided into three groups, of which 30 women were in the aerobics exercisers group, 30 women in yoga exercisers group, and 27 students in a group of physically inactive women. The participants were aged 20-26 years. Through anonymous surveys we examined the level of physical activity of respondents, health and psychological status and quality of life of women. The results were correlated between all three groups of subjects, and between recreationally active exercisers and physically inactive women.

Our findings confirm existing attitudes about the positive impact of recreational physical activity on mental and physical health and quality of life.

The results of the survey entirely correspond to the initial claims. We confirmed the hypothesis about the positive effects of regular recreational physical activity on mental and physical health and quality of life. The beneficial effects of an active lifestyle proved to be in the health survey, and in the responses relating to the mental health of women too.

Aerobics and yoga were specifically selected for this study, since they represent attractive forms of recreational exercise in women these days. They have proved to be very useful styles of a healthy lifestyle, which in addition to numerous effects on mental and physical health, improve quality of life.

In the previous research, many positive effects of physical activity on emotional states are described. Physical activity enables positive emotions. "Exercise high" is a state of euphoria, when the exerciser is experiencing cheerfulness, exhilaration, and other improvements of mood, such as the reduction of anxiety, tension and confusion (McArdle \& Katch, 1991).

Regular exercise suppresses negative, unpleasant emotions, and it causes anti-stress effect and positive mood (Guyton, 1991). Exercise leads to the development of a healthy personality (Paranosić, 1982) and the formation of mature and stable personality (Pierce \& Pate, 1994).

For a long time ruled attitude, that after early development and maturation period of the nervous system, the parts of the brain is stable and unchanging structure. However, new findings suggest plastic changes at different levels, both at the level of representational maps, and the changes in activity of small groups of individual neurons and synapses too. The scientific works of this type were observed plastic changes in the function and structure of neurons and neuron groups (especially synaptic connections), many structures of the brain, especially changes in the cortex in the cerebral hemispheres. Attitudes about plastic reorganization of the cortex are accepted, in the interaction of the organism with the environment.

The term cortical plasticity can be defined as a series of adaptive changes in the functional and morphological characteristics of the cerebral cortex. Challengers of the plastic reorganization of the brain may be different, such as afferent stimulation; pharmacological modulation; plasticity caused by a lesion; plasticity caused by stimulation of the cerebral cortex, and to a large extent the motoric training - motoric learning, respectively exercise movements directed on the adopt of motor skills.

Motor skills are acquired by repeating execution of motor tasks and motor workout. If during the life, some receptors or voluntary muscles are used intensively, their surface representations in sensory and motor cortex increase. When training a specific part of the body, its projection areas in the brain expand. This happens with frequent and repetitive movements, which are performed to gain or maintain professional motor skills (athletes). 
This competence of projection zone of the cerebral cortex, to adapt to changes, is known as plasticity, or adaptability of the brain function. These types of adaptations are one of the strongest stimulants that start functional reorganization of the motor cortex (Ilić, T. \& Ilić, V., 2012, Stevanović, 2009).

In contrast to all this, the reorganization of the motor cortex also arises as a consequence of prolonged inactivity, and in extended sensomotor recreation activities situation. Immobilization leads to hypotrophy, reduction of muscle mass and strength, and there is a decline in motor skills performance. These cases also cause a reorganization of primary motor cortex.

For the performance of motor tasks, it is necessary influx of sensomotor inputs. Afferent signals from cutaneous and muscle receptors are changing the excitability of neurons in the sensorimotor cortex. The importance of afferent inputs to perform complex motor tasks, confirmed the research in which the ascending projections were damaged.

It was found, that the removed representation of any part of the body, quickly establish using a new place in cortex. For larger deficits, for example, when the projection of the affected part of the body is in one hemisphere, occurs expansion the representation part of body in the opposite hemisphere.

Cortex adapts to changes in life, it has a high potential for plastic reorganization, and includes a number of changes in the interaction with the external environment (Stevanović, 2009; Ilić, T. \& Ilić, V., 2012).

Physical activity is a natural and necessary need of all people, and should be integrated into our daily lives. It is a condition for the preservation of human health and the normal functioning of the body. The paper highlights the importance of regular physical activity as an essential element of human health and existence.

Physical activity promote programs should be focused on increasing the number of promotional campaigns, to highlight the importance of beneficial effects of exercise and positive lifestyle changes. Active lifestyle is a way of life, based on regular physical activity and healthy habits. Active lifestyle is our greatest tool in reaching health and vitality.

Care to expand active participants in sports and recreational activities, and promotion of regular physical activity are significant health, and cultural needs. This is one of the priority tasks of modern society.

Promoting physical activity involves multisectoral cooperation, with the inclusion of the ministry, government, the health sector in joint cooperation, with a focus on promoting and educating the population about the importance of physical activity for health. Programs should develop mechanisms for better information about physical activity.

Recreational exercise in a suitable intensity and volume is recommended to young and to older people too, as a health routine (Meusel, 1990). Physical activity is recommended for any age and regardless of gender, and has a beneficial effect on mental and physical health and quality of life. 


\section{References}

Baranowski, T., Bouchard, C., Bar-Or, O., Bricker, T., Heath, G., Kimm. S., ... Washington, R. (1992). Assessment, prevalence, and cardiovascular benefits of physical activity and fitness in youth. Medicine and Science in Sports and Exercise, 24(6), 237-247.

Bauman, A., Lewicka, M., \& Schöppe, S. (2005). The Health Benefits of Physical Activity in Developing Countries. Geneva: World Health Organization.

Bouchard, C. (2007). Physical Activity and Health. Champaign (IL): Human Kinetics.

Golubić, R. (2010). Domene kvalitete života kao prediktori radne sposobnosti bolničkih zdravstvenih djelatnika. Zagreb: University of Zagreb, Medical School Repository.

Guyton, A. C. (1991). Textbook of Medical Physiology. London: WB Saunders Company.

Haskell, W. L., Lee, I. M., Pate, R. R., Powell, K. E., Blair, S. N., Franklin, B. A., . . Bauman, A. (2007). Physical activity and public health. Journal of the American Heart Association, $116,1081-1093$.

Ilić, T., \& Ilić, V. (2012). Plastična reorganizacija ljudskog motornog korteksa. Vojnosanitetski pregled, 69(10), 891-898.

Ivetić, M., \& Filipović, D. (2011). Fiziološke osnove motivacija i emocija. Novi Sad, Srbija: Univerzitet u Novom Sadu: ACIMSI; Centar za sportsku medicinu sa fizikoterapijom;.

Killoran, A. J., Fentem, P., \& Casperson, C. (1994). Moving on: International Perspective on Promoting Physical Activity. London: Health Education Authority.

Macera, C., Hootman, J., \& Sniezek, J. (2003). Major public health benefits of physical activity. Arthritis and Rheumatism, 49(1), 122-128.

McArdle, D. W., Katch, F. I., \& Katch, V. L. (1991). Exercise physiology; Energy, Nutrition and Human Performance. Philadelphia/London: Lea \& Febiger.

Medved, R. (1987). Sportska medicina. Zagreb: Jumena.

Meusel, H. (1990). Motor activity-healthy development-aging successfully? Gerontology, 23(5), 267-274.

Ministarstvo zdravlja Republike Srbije. (2006). Strategija za prevenciju i kontrolu hroničnih nezaraznih bolesti u Republici Srbiji. Beograd: Autor.

Paranosić, V. (1982). Psihologija sporta. Beograd: Partizan.

Pierce, E. F., \& Pate, D. W. (1994). Mood alterations in older adults following acute exercises. Perceptual and Motor Skills, 79(1), 191-194.

Sharkey, B., \& Gaskill, S. (2008). Vežbanje i zdravlje. Beograd: Data Status.

Stevanović, J. (2009). Fiziologija nervnog sistema. 2. dopunjeno izdanje. Novi Sad: Ortomedics.

Stojiljković, S. (2008). Fizička aktivnost i zdravlje. Medicinska praksa, 26(29-30), 133-157.

Stojiljković, S. (2011). Fizička aktivnost i ljudsko zdravlje. Sport i zdravlje, 1, 54-59.

Ugarković, D. (2011). Osnovi sportske medicine. 4. izdanje. Beograd: Viša košarkaška škola.

World Health Organization. (2005). Preventing Chronic Diseases: a Vital Investment: WHO global report. Geneva: Author.

World Health Organization. (2006). Gaining Health. The European Strategy for the Prevention and Control of Non communicable Diseases. Geneva: Author. 